\title{
Relative Contribution of Monooxygenase and Esterase to Pyrethroid Resistance in Triatoma infestans (Hemiptera: Reduviidae) from Argentina and Bolivia
}

\author{
PABLO L. SANTO ORIHUELA, CLAUDIA V. VASSENA, \\ EDUARDO N. ZERBA, AND MARÍA I. PICOLLO ${ }^{1}$ \\ Centro de Investigaciones de Plagas e Insecticidas (CITEFA-CONICET), Juan Bautista de \\ La Salle 4397, (B1603ALO), Buenos Aires, Argentina
}

\section{J. Med. Entomol. 45(2): 298-306 (2008)}

\begin{abstract}
Recently, high resistance to pyrethroid insecticides has been associated with ineffective field treatments against Triatoma infestans (Klug) (Hemiptera: Reduviidae) in northern Argentina. Samples were collected from two areas in Argentina (Salta and La Rioja) and one are in Bolivia (Yacuiba), and they were subjected to toxicological and biochemical assays. All populations were resistant to deltamethrin, but they showed different profiles to nonpyrethroid insecticides. The Salta population showed high resistance ratios (RRs) to deltamethrin and only slight differences in the susceptibility to fenitrothion and fipronil compared with the reference strain. Otherwise, the La Rioja population showed a lower RR to deltamethrin and no resistance to fenitrothion or fipronil. Finally, the Yacuiba population had high a RR to deltamethrin, but it was susceptibility to fenitrothion and fipronil. In several cases, deltamethrin-resistant populations had higher susceptibility to bendiocarb than the reference strain. Measured activity of P450 monooxygenase in individual insects (based on ethoxycoumarine-O-deethylase), tended to be higher in the deltamethrin-resistant populations, but the differences were not statistically significant. Activity of specific esterases determined by the hydrolysis of 7-coumaryl permethrate demonstrated an increase in the percentage of insects with higher esterase activity in the Salta and La Rioja populations. Unexpectedly, the Yacuiba population showed lower pyrethroid esterase activity than the reference strain. The different pyrethroid resistance patterns found in T. infestans from three geographical regions within Argentina and in Bolivia suggests that enzyme-based pyrethroid resistance in this species has multiple origins. Nevertheless, because nerve insensitivity (related to the presence of the $k d r$ gene) is also an important mechanism related to pyrethroid resistance, further studies on the $k d r$ gene should be carried to clarify the relative contribution of each pyrethroid-associated mechanism in deltamethrin-resistant populations of $T$. infestans.
\end{abstract}

KEY WORDS Triatoma infestans, insecticide resistance, resistance ratios, monooxygenase, pyrethroid esterase

Triatoma infestans (Klug) (Hemiptera: Reduviidae) is a blood-sucking bug and the main vector of Chagas' disease in Argentina. National control campaigns against this vector have been based on pyrethroid insecticides for $>20 \mathrm{yr}$. However, resistance to pyrethroids has been detected in certain areas of Argentina since 1997 (Vassena and Picollo 2003, González Audino et al. 2004).

In 2002, high resistance to pyrethroid insecticides was associated with ineffective field treatments against T. infestans in northern Argentina (Picollo et al. 2005). Resistance to pyrethroids in a variety of insects has been found to be associated with elevated monooxygenases and esterases (Wilkinson 1983, Oppenoorth 1984). These enzymes contribute to resis-

${ }^{1}$ Corresponding author, e-mail: mpicollo@citefa.gov.ar. tance by rapid hydrolysis of insecticides to their nontoxic forms (Karunaratne 1998, Hemingway et al. 2004). Resistance associated with increased metabolism in T. infestans was found in a deltamethrin-resistant field population from Salta, Argentina (González Audino et al. 2004). This study demonstrated a consistent correlation between elevated monooxygenase activity as determined on individual abdomens through ethoxycoumarin- $O$-deethylase (ECOD) activity, and deltamethrin resistance. Moreover, the study showed a significant difference in nonspecific esterase activity measured as phenyl-thioacetate and $\alpha$-naphtyl acetate activities between the susceptible and Salta populations. Later, a new fluorescent substrate for examining pyrethroid-cleaving esterases was reported by Santo Orihuela et al. (2006). The high sensitivity of this fluorescent technique allowed the 


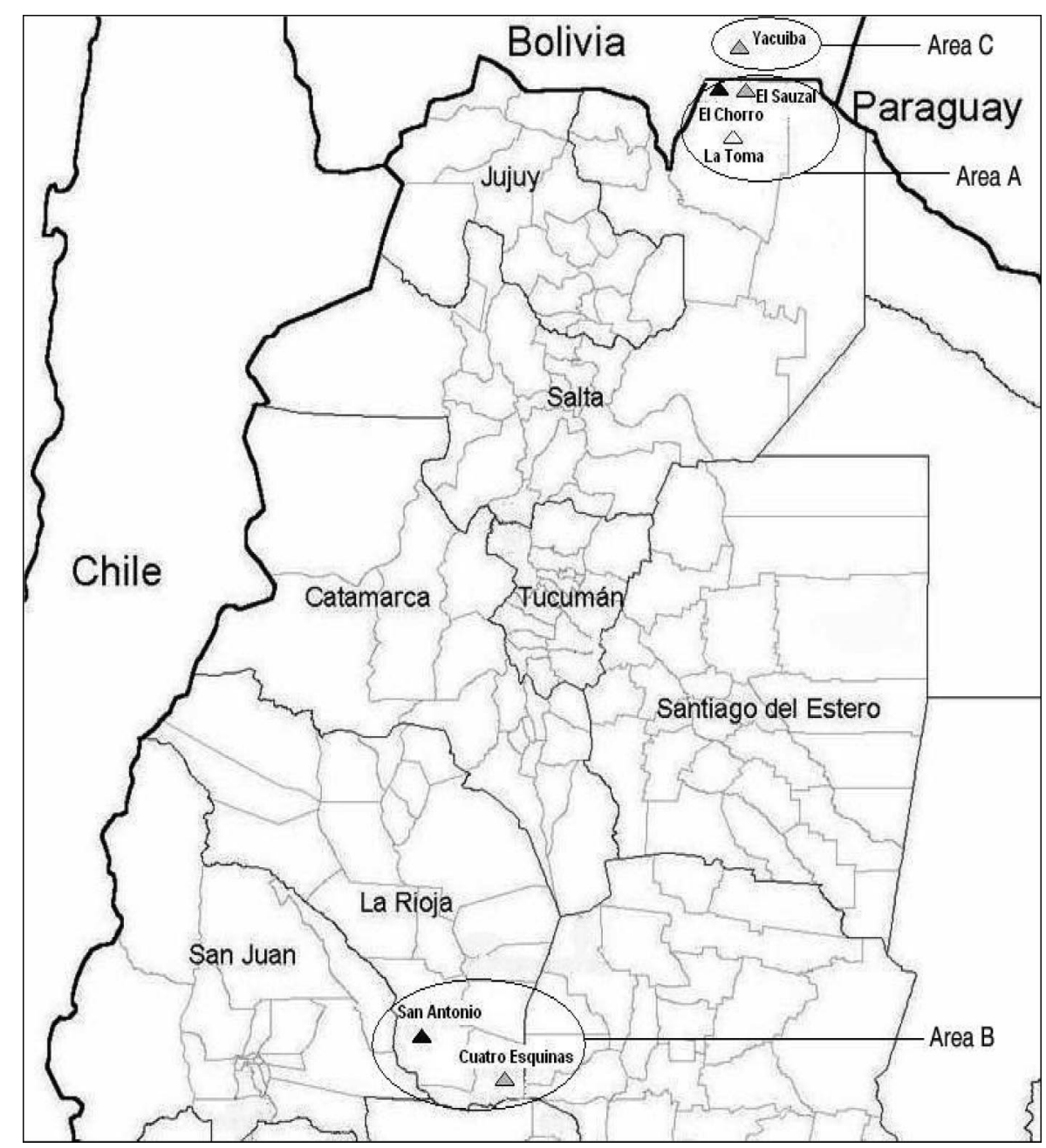

Fig. 1. Collections sites for samples of insects from northern Argentina and southern Bolivia.

quantification of pyrethroid esterase activity on individual insects, an important tool to assess the distribution of esterase activity in individual from susceptible and resistant populations.

In this study, esterase and monooxygenase microtiter plate assays were used for evaluating the frequency distribution of enzyme activities among resistant populations of T. infestans from two regions in Argentina and in Yacuiba, Bolivia. Our objective was the study of the relative contribution of pyrethroid esterases and P450 monooxygenases in pyrethroid-resistant $T$. infestans.

\section{Materials and Methods}

Insect Sampling. Field populations of T. infestans were collected in May 2005 from infested houses of three geographical regions in Argentina and Bolivia. The chosen regions represented areas previously identified as having resistant $T$. infestans based on the laboratory test, areas with reported ineffectiveness of the field application of pyrethroids, or both. The collection sites in each area are described below (Fig. 1).
Area A. The El Chorro, La Toma, and El Sauzal sites are located in the San Martín Department $\left(22^{\circ} 03^{\prime} \mathrm{S}\right.$, $\left.63^{\circ} 41^{\prime} \mathrm{W}\right)$, Salta Province, Argentina. This is a subtropical area with a warm climate (maximum summer temperature $38^{\circ} \mathrm{C}$; minimum winter temperature $\left.9^{\circ} \mathrm{C}\right)$. Several insecticides have been intensively used in this area against $T$. infestans (mainly deltametrin, but also $\lambda$-cyhalothrin and $\beta$-cypermethrin) and against Aedes aegypti (L.) (deltamethrin and fenitrothion). In 2002, vector control authorities reported ineffectiveness of pyrethroid insecticides, and high levels of resistance were detected in the laboratory. Resistance ratios (RRs) were 99.0, 86.9, and 50.5 for El Chorro, La Toma, and El Sauzal (Picollo et al. 2005). Samples from this area were provided by Mario Zaidemberg (Ministry of Health of Argentina).

Area B. The Cuatro Esquinas, San Martín Department $\left(31^{\circ} 48^{\prime} \mathrm{S}, 65^{\circ} 52^{\prime} \mathrm{W}\right)$, and San Antonio, Facundo Quiroga Department $\left(31^{\circ} 05^{\prime} \mathrm{S}, 66^{\circ} 44^{\prime} \mathrm{W}\right)$ sites are located to the south of La Rioja Province, Argentina, and they are in one of the most arid and poorest regions of Argentina. The climate is colder than in area 
A (average maximum temperature $19.3^{\circ} \mathrm{C}$; average minimum temperature $-5^{\circ} \mathrm{C}$ ). As part of the Chagas disease vector control program, rural houses in this region were first sprayed with organochlorine insecticides in the late 1950s and extensively sprayed with pyrethroid insecticides during the 1980s (Segura 2002). By the early 1990s, the decentralization of the national program resulted in a virtual cessation of vector control activities during the next $10 \mathrm{yr}$, except for individual houses irregularly sprayed by nonprofessional personnel (Porcasi et al. 2006). In 2003, deltamethrin resistance was detected in laboratory tests that were not correlated with failures of chemical control in the field. The RRs were 14.1 and 21.1 for Cuatro Esquinas and San Antonio (Vassena et al. 2007). Samples from this area were provided by Cynthia Spillman (Ministry of Health, Argentina).

Area C. Yacuiba is located in southern Bolivia (Tarija Department) $\left(22^{\circ} 00^{\prime} \mathrm{S} 63^{\circ} 40^{\prime} \mathrm{W}\right)$. Weather is hot and dry (maximum temperature $43^{\circ} \mathrm{C}$; minimum temperature $7^{\circ} \mathrm{C}$ ). Chemical control in this area has been mainly done with $\alpha$-cypermethrin since 1991 when the World Health Organization started the Southern Cone Initiative for interruption of vectorial transmission (Moncayo 2003). In 2003, serious levels of infestation after chemical control of field insects were reported by Abraham Jemio (Ministry of Health and Sports, Bolivia). Later, high deltamethrin resistance was established in the laboratory $(\mathrm{RR}=154.4)$.

The laboratory reference strain was the susceptible CIPEIN, which has been reared in our laboratory since 1975 (Picollo et al. 1976). A field population collected in April 2004 in an area where there had been no control failures or other indications of possible resistance was used as field reference strain. This population was collected in the Figueroa Department, located in the Santiago el Estero Province $\left(28^{\circ} 26^{\prime} \mathrm{S}, 63^{\circ} \mathrm{C}\right.$ $33^{\prime} \mathrm{W}$ ). The climate is dry and hot (maximum temperature $47^{\circ} \mathrm{C}$; minimum temperature $-5^{\circ} \mathrm{C}$ ), showing high thermal amplitude.

All populations were maintained in the laboratory at $28 \pm 1{ }^{\circ} \mathrm{C}, 50 \% \mathrm{RH}$ and a photoperiod of 12:12 (L:D) h. Bugs were fed weekly on pigeons.

For all the experiments, laboratory-reared first instars ( $3 \mathrm{~d}$ old) were starved since eclosion (mean weight $1.2 \pm 0.2 \mathrm{mg}$ ). They were selected for the tests according to the World Health Organization protocol (WHO 1994).

Chemicals. Technical grade insecticides used for bioassay were fenitrothion (97\%; Sumitomo, Osaka, Japan), deltamethrin (97\%; Bayer, Buenos Aires, Argentina), fipronil (96.5\%; Dr. Ehrenstorfer $\mathrm{GmbH}$, Augsburg, Germany), and bendiocarb (98.5\%; Dr. Ehrenstorfer $\mathrm{GmbH}$ ). 7-Ethoxycoumarin (7-EC) and 7-hydroxycoumarin (7-OHC) (umbelliferone) were from Sigma-Aldrich (St. Louis, MO). cis-trans ( $43.8 \%$ cis; $56.2 \%$ trans $)$-Permethrinic acid was supplied from Chemotecnica (Buenos Aires, Argentina), and thionyl chloride $\left(\mathrm{Cl}_{2} \mathrm{SO}\right)(99 \%)$ and triethylamina (+99\%) were purchased from Aldrich Chemical (Milwaukee, WI). 7-Coumaryl permethrate (7-CP) was synthe- sized in our laboratory by the method of Santo Orihuela et al. (2006).

Topical Application Bioassays. Serial dilutions of the tested insecticides in acetone were prepared and topically applied with a $10-\mu$ l Hamilton microsyringe provided with a repeating dispenser. Each nymph was treated with $0.2 \mu \mathrm{l}$ of the solution on the dorsal surface of the abdomen (WHO 1994). Total dose ranged from $2 \times 10^{-3}$ to $200 \mathrm{ng}$ per insect.

At least 10 insects per dose and per replicate were used. A minimum of three doses, giving $>0$ and $<100 \%$ mortality, were used for each treatment. Each experiment was replicated at least three times. Control groups received acetone.

Treated and control insects were placed onto filter paper discs. Insects were housed in an environmental chamber (Lab-Line Instruments, Melrose Park, IL) at $28 \pm 1^{\circ} \mathrm{C}, 55 \pm 5 \% \mathrm{RH}$, and a photoperiod of 12:12 (L:D) $\mathrm{h}$.

Mortality was recorded at $24 \mathrm{~h}$ after treatment. The criterion for mortality was the inability of the nymphs to walk from the center to the border of a $7-\mathrm{cm}$ paper disc (Vassena et al. 2000, Picollo et al. 2005). Mortality data were corrected using Abbott's formula (Abbott 1987)

Cytochrome P450 Monooxygenase. Activity was measured using 7-EC as substrate, according to the direct fluorometric test method for liver microsomes by Ullrich and Weber (1972) and adapted for individual Drosophila melanogaster (Meigen) abdomens by de Sousa et al. (1995) and for individual abdomens of $T$. infestans and Pediculus humanus capitis (De Geer) by Bouvier et al. 1998 and González Audino et al. (2005). Fluorescence of 7-OHC was determined using microplate fluorescence reader (FluoroCount, PerkinElmer Life and Analytical Sciences, Boston, MA), with 400-nm excitation and 440-nm emission filters.

First instar abdomens were placed individually into wells of a 96-well microplate containing $100 \mu \mathrm{l}$ of 0.05 $\mathrm{M}$ phosphate buffer and $4 \mathrm{mM} 7$-EC. The reaction was stopped after 4 -h incubation at $30^{\circ} \mathrm{C}$ by adding $100 \mu \mathrm{l}$ of glycine buffer $\left(10^{-4} \mathrm{M}\right), \mathrm{pH} 10.4$. To precipitate the abdomens in the wells, microplates were centrifuged at $2000 \times g$ for $30 \mathrm{~s}$ in a refrigerated centrifuge for microplates (4237 R, ALC International SRL, Cologna Monzese, Italy) before and after the incubation of the enzymatic reaction at $30^{\circ} \mathrm{C}$. For each population, similar wells receiving glycine buffer before incubation were used as blanks.

Esterase Activity. Esterase activity was determined by the hydrolysis of 7-CP, a new fluorescent substrate appropriate for determining pyrethroid hydrolysis activity on individual insects (Santo Orihuela et al. 2006). For this, the insects were cooled, and each nymph was homogenized in $220 \mu$ l of phosphate buffer $(0.05 \mathrm{M})$, pH 7.2, by using a plastic mortar and pestle. Reaction was initiated by adding $10 \mu$ l of 7-CP (3.5 mM, 2-methoxy ethanol) to $190 \mu \mathrm{l}$ of each homogenate. Incubation was performed at $25^{\circ} \mathrm{C}$ for 33 min, at $\mathrm{pH}$ 7.2. The fluorescence was measured using a microplate fluorescence reader (FluoroCount), and 
Table 1. Toxicity of insecticides against deltamethrin-susceptible (CIPEIN) and deltamethrin-resistant T. infestans from Salta and La Rioja (Argentina) and Yacuiba (Bolivia)

\begin{tabular}{|c|c|c|c|c|c|c|}
\hline Insecticide & Area & Pop & $n$ & Slope \pm SE & $\mathrm{LD}_{50} \mathrm{ng} /$ insect $(95 \% \mathrm{CL})$ & $\mathrm{RR}(95 \% \mathrm{CL})^{a}$ \\
\hline \multirow[t]{8}{*}{ Deltamethrin } & & CIPEIN $^{b}$ & 125 & $2.10 \pm 0.66$ & $0.13(0.12-0.15)$ & \\
\hline & & Figueroa & 129 & $2.34 \pm 0.38$ & $0.22(0.09-0.38)$ & \\
\hline & A & El Chorro $^{b}$ & 220 & $1.90 \pm 0.14$ & $12.80(11.00-14.86)$ & $99.0(78.2-125.3)$ \\
\hline & & La Toma $^{b}$ & 100 & $1.90 \pm 0.14$ & $11.27(6.06-23.30)$ & $86.9(68.1-111.0)$ \\
\hline & & El Sauzal $^{b}$ & 90 & $1.47 \pm 0.11$ & $6.54(2.26-19.39)$ & $50.5(30.7-83.1)$ \\
\hline & B & C. Esquinas & 90 & $1.41 \pm 0.11$ & $1.83(1.01-3,3)$ & $14.09(11.46-17.33)$ \\
\hline & & San Antonio & 100 & $1.70 \pm 1.28$ & $2.79(1.53-5.16)$ & $21.09(16.52-26.94)$ \\
\hline & $\mathrm{C}$ & Yacuiba & 150 & $1.45 \pm 0.15$ & $28.42(18.30-53.77)$ & $154.4(121.2-169.0)$ \\
\hline \multirow[t]{7}{*}{ Fenitrothion } & & CIPEIN $^{b}$ & 150 & $1.42 \pm 0.11$ & $21.60(5.3-67.93)$ & \\
\hline & A & El Chorro $^{b}$ & 120 & $1.66 \pm 0.15$ & $26.97(1.81-69.33)$ & $1.29(0.97-1.70)$ \\
\hline & & La Toma $^{b}$ & 120 & $1.53 \pm 0.14$ & $25.72(21.88-30.24)$ & $1.54(1.16-2.05)$ \\
\hline & & El Sauzal $^{b}$ & 90 & $2.39 \pm 0.25$ & $36.11(31.76-41.06)$ & $1.78(1.36-2.34)$ \\
\hline & $\mathrm{B}$ & C. Esquinas & 120 & $1.06 \pm 0.1$ & $4.02(1.08-11.14)$ & $0.19(0.14-0.25)$ \\
\hline & & San Antonio & 130 & $1.44 \pm 0.11$ & $3.69(2.30-55.98)$ & $0.17(0.13-0.23)$ \\
\hline & $\mathrm{C}$ & Yacuiba & 120 & $2.24 \pm 0.16$ & $17.03(12.82-22.05)$ & $0.79(0.62-1.02)$ \\
\hline \multirow[t]{7}{*}{ Fipronil } & & CIPEIN & 150 & $1.42 \pm 0.11$ & $2.12(1.28-3.46)$ & \\
\hline & A & El Chorro & 120 & $1.09 \pm 0.11$ & $4.02(2.84-5.68)$ & $1.88(1.03-3.44)$ \\
\hline & & La Toma & 120 & $1.01 \pm 0.10$ & $3.44(2.46-4.80)$ & $1.40(0.76-2.57)$ \\
\hline & & El Sauzal & 90 & $1.02 \pm 0.10$ & $4.27(3.25-5.61)$ & $1.80(1.01-3.20)$ \\
\hline & $\mathrm{B}$ & C. Esquinas & 120 & $0.74 \pm 0.01$ & $2.57(1.84-2.89)$ & $1.16(0.58-2.29)$ \\
\hline & & San Antonio & 120 & $1.73 \pm 0.21$ & $0.54(0.42-0.61)$ & $0.22(0.12-0.39)$ \\
\hline & $\mathrm{C}$ & Yacuiba & 180 & $1.02 \pm 0.10$ & $3.31(1.33-8.22)$ & $1.46(0.79-2.69)$ \\
\hline \multirow[t]{7}{*}{ Bendiocarb } & & CIPEIN & 150 & $3.21 \pm 0.41$ & $1.45(1.16-1.77)$ & \\
\hline & A & El Chorro & 120 & $1.51 \pm 0.14$ & $1.16(0.44-3.01)$ & $0.67(0.53-0.84)$ \\
\hline & & La Toma & 150 & $2.52 \pm 0.21$ & $1.71(1.45-2.03$ & $1.03(0.81-1.131)$ \\
\hline & & El Sauzal & 180 & $1.60 \pm 0.15$ & $1.16(0.99-1.59)$ & $0.50(0.37-0.69)$ \\
\hline & $\mathrm{B}$ & C. Esquinas & 120 & $1.71 \pm 0.15$ & $0.59(0.46-0.75)$ & $0.45(0.35-0.58)$ \\
\hline & & San Antonio & 120 & $2.31 \pm 0.18$ & $1.66(1.42-1.96)$ & $1.02(0.81-1.31)$ \\
\hline & $\mathrm{C}$ & Yacuiba & 150 & $1.51 \pm 0.15$ & $1.60(1.35-1.89)$ & $1.02(0.74-1.40)$ \\
\hline
\end{tabular}

${ }^{a} \mathrm{RR} \pm 95 \% \mathrm{CL}$ was calculated according Robertson and Preisler (1992).

${ }^{b}$ Data from Picollo et al. (2003).

results were analyzed with FluoroCount and Excel 2000 (Microsoft, Redmond, WA) software. Assays were conducted in black 96-well polystyrene flat-bottomed microtiter plates (PerkinElmer Life and Analytical Sciences) at $25^{\circ} \mathrm{C}$. Production of $7-\mathrm{OHC}$ was monitored with excitation wavelength at $400 \mathrm{~nm}$ and emission at $440 \mathrm{~nm}$, with the instrument gain set to 4.0 and the light intensity set to 12 . Activity was measured every $3 \mathrm{~min}$ for $33 \mathrm{~min}$, with the assay being linear over this time. The relative fluorescence units (RFU) were all corrected for background hydrolysis, nonspecific fluorescence of substrate, and transformed to picomoles per minute (activity units) by using a calibration curve per replicate with dilutions of 7-OHC (68.5, $342.69,685.44$, and 1370.8 total pmol per well).

Statistical Analysis. Mortality data were corrected using Abbott's formula (Abbott 1987). Bioassay data from each $T$. infestans population were pooled and analyzed based on probit analysis (Litchfield and Wilcoxon 1949). Doses predicted to give 50\% lethality $\left(\mathrm{LD}_{50}\right.$ values) were expressed as nanograms of insecticide per insect. To compare lethal dose and estimate whether the $\mathrm{LD}_{50}$ of an apparently resistant populations differed significantly from the $\mathrm{LD}_{50}$ of the susceptible strain, the ratio of $\mathrm{LD}_{50}$ values of the two strains and the $95 \%$ CL for the ratio were calculated. If the $95 \%$ confidence interval includes 1.0 , then the $\mathrm{LD}_{50}$ values of the two strains are considered not significantly different (Robertson and Preisler 1992).

The biochemical data were plotted as the percentage of individuals responding within a particular range of values of enzyme activity (Sokal and Rohlf 1980). A reasonable threshold of enzyme activity containing the majority of insects $(>64 \%)$ was established for the susceptible strain, and the percentage of insects over the threshold was calculated for each enzyme and each population (Picollo et al. 2005).

\section{Results}

The susceptibility to deltamethrin in the field reference population (Figueroa) was evaluated and compared with the laboratory reference population (CIPEIN). The $\mathrm{LD}_{50}$ values were $0.22 \mathrm{ng}$ per insect for the field population and $0.13 \mathrm{ng}$ per insect for the laboratory strain. The $95 \%$ CL overlap indicated similar toxicity due to deltamethrin between the laboratory and the field reference strain, and it demonstrated that CIPEIN strain give a realistic comparison with natural levels of insecticide tolerance (Table 1). The toxicity of fenitrothion, fipronil, and bendiocarb when the laboratory reference strain and field populations were exposed by topical application also is summarized in Table 1.

The RR estimated for insects from northern Argentina (area A) showed high levels of resistance to deltamethrin (El Chorro, RR= 99.0; La Toma, $R R=86.9$; and El Sauzal, RR $=50.5$ ). The 95\% CL for CIPEIN with fenitrothion were very wide, but there was some indication of slight resistance of La Toma and El Sauzal $(\mathrm{RR}=1.64$ and 1.78 , respectively $)$ to fenitrothion. 
Surprisingly, two populations from area A showed RR values for bendiocarb lower than 1.0 (El Chorro, $\mathrm{RR}=0.67$; and El Sauzal, RR =0.5), which indicates that these deltamethrin-resistant insects are more susceptible to bendiocarb than the deltamethrin-susceptible strain.

The toxicity test on T. infestans from southern La Rioja (area B) demonstrated deltamethrin-resistance in both samples (Cuatro Esquinas, $R R=14.09$; and San Antonio, RR = 21.09). These RR values were high, but they were not as high as those estimated for populations from northern Argentina (area A). In contrast, some of the RR values for fenitrothion, fipronil, and bendiocarb were lower than 1.0, indicating that some of the deltamethrin-resistant insects in this area were slightly more susceptible to these insecticides than the deltamethrin-susceptible strain (Cuatro Esquinas, $\mathrm{RR}=0.19,1.16$, and 0.45 respectively; San Antonio, $\mathrm{RR}=0.17,0.22$, and 1.02 , respectively).

Table 1 also shows the resistant state of the $T$. $i n$ festans population from southern Bolivia (area C). These insects showed high resistance to deltamethrin $(\mathrm{RR}=154.4)$, but they did not differ significantly from CIPEIN in susceptibility to fenitrothion, fipronil, or bendiocarb.

The activities of degradative enzymes that might be associated with deltamethrin resistance (P450 monooxygenases and pyrethroid esterases) were determined on individual first-stage nymphs of susceptible and resistant populations. The frequency distribution of 7-OHC activities among deltamethrin-susceptible and -resistant T. infestans is shown in Fig. 2., and the frequency distribution of pyrethroid esterase activity is shown in Fig. 3. In these histograms, vertical lines are marked at values of $0.48 \mathrm{pmol} / \mathrm{min}$; and on each histogram, the percentage of individuals exceeding this value is marked. In Fig. 2, these percentages were 36\% for CIPEIN and 43-63\% for most of the deltamethrinresistant populations. However, a simple analysis of variance (ANOVA) demonstrated that there were no significant differences in 7-OHC activity between the deltamethrin-susceptible and -resistant populations $(P=0.2929)$.

Unexpectedly, the Bolivian insects (Yacuiba) showed a different pattern of permethrate-esterase frequency distribution, with most insects having lower enzyme activity than the susceptible strain.

\section{Discussion}

Variation in the detoxifying capacity of insects is responsible, at least in part, for the development of resistance to insecticides. Cytochrome P450 monooxygenases and esterases are the major metabolic mechanisms responsible for pyrethroid resistance (Wilkinson 1983, Oppenoorth 1984, Yang et al. 2004).

Resistance to deltamethrin in vectors of Chagas Disease, was previously associated with increased oxidative metabolism in Brazilian T. infestans and Venezuelan Rhodnius prolixus (Stål) (Vassena et al. 2000) and associated with increased activity of esterases and monooxygenases in Argentinean T. infestans (González Audino et al. 2004).

In this study, the relative contribution of degradative enzymes was evaluated against $T$. infestans populations from two different areas ( $\mathrm{A}$ and $\mathrm{B}$ ) in Argentina and one area in Bolivia. The laboratory reference strain was the CIPEIN strain, which showed similar susceptibility to deltamethrin as a recently collected field population (Figueroa) from an area where there had been no control failures or other indications of possible resistance.

Results from toxicological tests demonstrated that all the studied populations were resistant to deltamethrin, but the level of deltamethrin resistance was least ( $\mathrm{RR}=14-21$ fold) in area B (Argentina), higher $(\mathrm{RR}=50-99)$ in area A (Argentina) and highest $(\mathrm{RR}=154)$ in Bolivia.

Any significant increases in resistance detected to fenitrothion, fipronil, or bendiocarb were slight. There was more convincing evidence that certain of the deltamethrin resistant populations had significantly more susceptibility to certain of these nonpyrethroids than did the CIPEIN deltamethrin-susceptible reference strain.

Negative cross-resistance between pyrethroids and organophosphorus insecticides has already been reported for Culex pipiens quinquefasciatus (Say), by Kolaczinski and Curtis (2004). These authors demonstrated that selection of a susceptible strain with permethrin for 19 generations rendered the strain more susceptible to the organophosphate malathion than the original strain. Similarly, a pattern of negative cross-resistance to indoxacarb was reported in pyrethroid-selected populations of Helicoverpa armigera (Hübner) from India (Ramasubramanian and Regupathy 2004). In their study, fenvalerate- and cypermethrin-selected populations were more susceptible to indoxacarb, a modern oxadiazine insecticide that needs activation mediated through carboxylesterase. They concluded that the increased level of carboxylesterase because of pyrethroid selection might activate indoxacarb to be more toxic, resulting in negative cross-resistance in the pyrethroid-selected populations.

From most of the deltamethrin-resistant populations have an increased percentage of individuals were observed with high ECOD activity than in CIPEIN. However, the apparent differences were not statistically significant. Although cytochrome P450 monooxygenase constitute a multigenic super family of enzymes, the ECOD activity measured using microplate tests, was viewed as a convenient measure of general P450 activity. Elevated ECOD activity has been associated with pyrethroid resistance in individual measurements on Cydia pomonella (L.) (Sauphanor et al. 1997), Aedes aegypti (L.) (Brengues et al. 2003, David et al. 2006), and Pediculus humanus capitis (De Geer) (González Audino et al. 2004). The esterase detoxification mechanism of pyrethroid resistance was significantly more active in two of the Argentinean deltamethrin-resistant populations, but the highly resistant Bolivian population has markedly less of this activity 


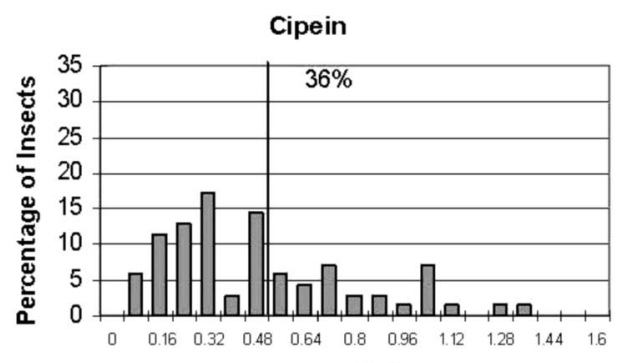

$\mathrm{pmol} / \mathrm{m}$ in
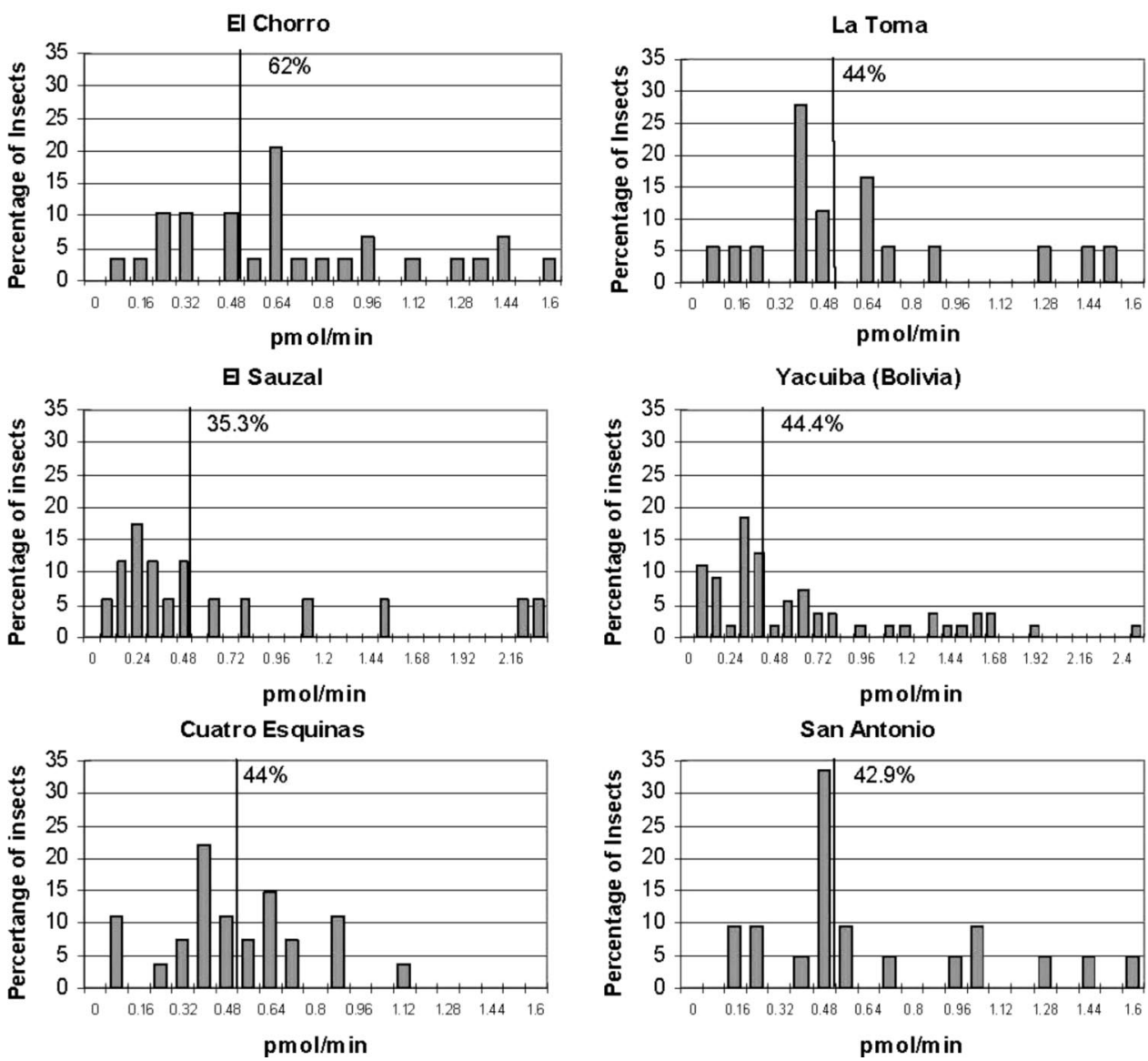

Fig. 2. Frequency distribution of P450 monooxygenase activity among deltamethrin-susceptible and -resistant $T$. infestans. Enzyme activity as picomoles of 7-OH coumarin per minute.

than CIPEIN. Thus, elevated esterases seem to contribute in pyrethroid resistance in Argentina only. Natural variations in $T$. infestans from several areas of both countries were reported previously. Monteiro et al. (1999) used mitochondrial DNA sequence variation to infer the genetic structure of nine T. infestans populations from Bolivia, Brazil, and Argentina. They found four haplotypes that could be separated into two clusters: one cluster consisting of insects from Bolivia and the other cluster of samples from Argentina and Brazil. Differentiation between T. infestans from Bolivia and Argentina/Brazil has also been carried out by cytogenetic methods (Panzera et al. 2004).
The relationship between enzyme activity and resistance was previously studied on fenvalerate-resistant H. armigera by Chen et al. (2005). They determined cytochrome P450 mediated o-demethylation activity toward $p$-nitroanisole (PNOD) of individual fourth instars in five strains by using a microplate reader. They also found a strong positive correlation between frequency distribution of PNOD activity and fenvalerate resistance: of 48 larvae from each strain, only $4 \%$ larvae of the susceptible strain had detectable PNOD activity, whereas $25,33,79$, and $96 \%$ of larvae from the resistant strains exhibited PNOD activity. Therefore, Chen et al. (2005) proposed PNOD activity 


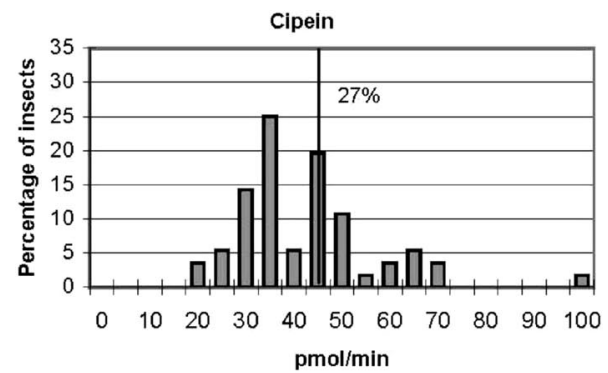

El Chorro
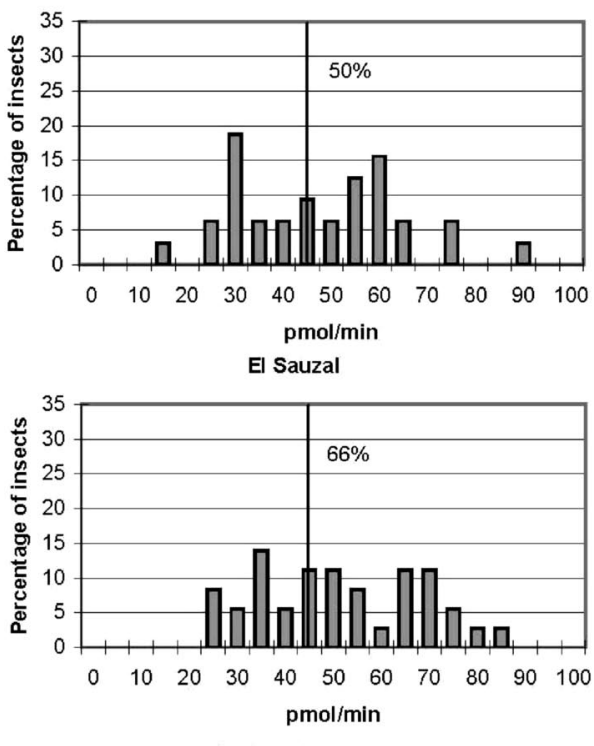

Cuatro Esquinas

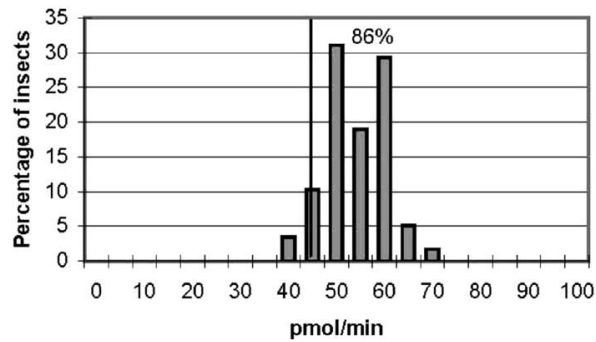

La Toma

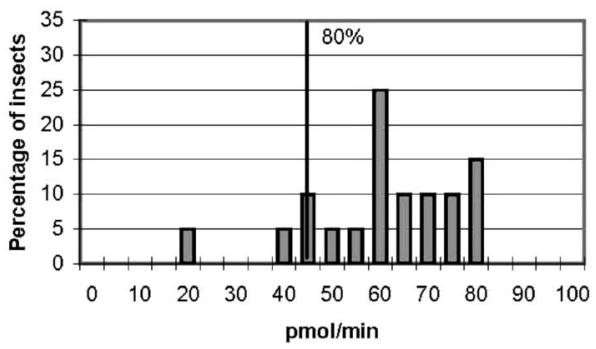

Yacuiba (Bolivia)

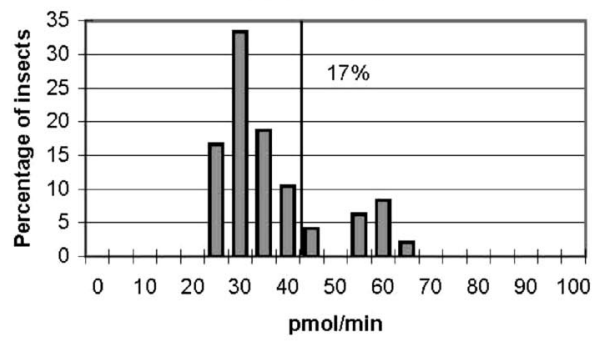

San Antonio

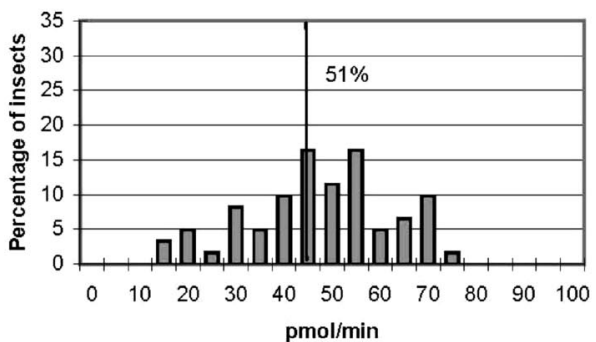

Fig. 3. Frequency distribution of permethrate esterase activity among deltamethrin-susceptible and -resistant T. infestans. Enzyme activity as picomoles of 7-OH coumarin per minute.

as a biochemical marker for monooxygenase-mediated pyrethroid resistance in field populations of $H$. armigera.

Rose et al. (1995) suggested that the high metabolic activity of a multiresistant population of tobacco budworm, Heliothis virescens (F.), measured on homogenates of individual larvae, might be used in resistance monitoring. By plotting the percentage of individuals responding within a particular range of enzyme activity by using a monooxygenase substrate ( $p$-nitroanisole) and an esterase substrate ( $p$-nitrophenil acetate), they demonstrated that both substrates were able to discriminate between pyrethroid resistant and susceptible individuals.
The biochemical resistance monitoring proposed by both Rose et al. (1995) and Chen et al. (2005) was based on microtiter plate assays that have proven to be capable of discriminating between susceptible and resistant individuals and consequently could allow predictions of resistance frequency.

The different pyrethroid-resistant pattern found in T. infestans from three geographical regions within Argentina and in Bolivia suggests that enzyme-based pyrethroid resistance in this species has multiple origins. However, nerve insensitivity (related to the presence of the $k d r$ gene) is also an important mechanism for pyrethroid resistance. Therefore, additional studies on the $k d r$ gene should be carried out to assess 
the relative contribution of each pyrethroid-associated mechanism in deltamethrin-resistant populations of T. infestans.

\section{Acknowledgments}

We thank to Drs. Cynthia Spillmann and Mario Zaidemberg and technicians from the Coordinación Nacional de Control de Vectores, Ministerio de Salud de Argentina, and Tamara Chavez and Abraham Jemio and technicians from Ministerio de Salud y Deportes de Bolivia, for the coordination of field sampling. This investigation received financial support from the UNICEF/UNDP/ World Bank/World Health Organization Special Programme for Research and Training in Tropical Diseases, and the Consejo Nacional de Investigaciones Científicas y Técnicas of Argentina. We thank Schofield for helpful comments and editorial assistance.

\section{References Cited}

Abbott, W. S. 1987. A method of computing the effectiveness of an insecticide. 1925. J. Am. Mosq. Control Assoc. 3: 302-303.

Bouvier, J., A. Cuany, C. Monier, V. Brosse, and B. Sauphanor. 1998. Enzymatic diagnosis of resistance to deltamethrin in diapausing larvae of the codling moth, Cydia pomonella (L.). Arch. Insect Biochem. Physiol. 39: 55-64.

Brengues, C., N. J. Hawkes, F. Chandre, L. Mccarroll, S. Duchon, P. Guillet, S. Manguin, J. C. Morgan, and J. Hemingway. 2003. Pyrethroid and DDT cross-resistance in Aedes aegypti is correlated with novel mutations in the voltage-gated sodium channel gene. Med. Vet. Entomol. 17: 87-94.

Chen, S., Y. Yang, and Y. Wu. 2005. Correlation between fenvalerate resistance and cytochrome P450-mediated $O$-demethylation activity in Helicoverpa armigera (Lepidoptera: Noctuidae). J. Econ. Entomol. 98: 943-946.

David, J. P., S. Boyer, A. Mesneau, A. Ball, H. Ranson, and C. Dauphin-Villemant. 2006. Involvement of cytochrome P450 monooxygenases in the response of mosquito larvae to dietary plant xenobiotics. Insect Biochem. Mol. Biol. 36: $410-420$.

de Sousa, G., A. Cuany, A. Brun, M. Amichot, R. Rahmani, and J. B. Berge. 1995. A microfluorometric method for measuring ethoxycoumarin-O-deethylase activity on individual Drosophila melanogaster abdomens: interest for screening resistance in insect populations. Anal. Biochem. 229: 86-91.

González Audino, P., C. Vassena, S. Barrios, E. Zerba, and M. I. Picollo. 2004. Role of enhanced detoxication in a deltamethrin-resistant population of Triatoma infestans (Hemiptera, Reduviidae) from Argentina. Mem. Inst. Oswaldo Cruz 99: 335-339.

González Audino, P., S. Barrios, C. Vassena, G. Mougabure Cueto, E. Zerba, and M. I. Picollo. 2005. Increased monooxygenase activity associated with resistance to permethrin in Pediculus humanus capitis (Anoplura: Pediculidae) from Argentina. J. Med. Entomol. 42: 342-345.

Hemingway, J., N. J. Hawkes, L. McCarroll, and H. Ranson. 2004. The molecular basis of insecticide resistance in mosquitoes. Insect Biochem. Mol. Biol. 34: 653-665.

Karunaratne, S. 1998. Insecticide resistance in insects: a review. Ceylon J. Sci. 25: 72-99.

Kolaczinski, J. H., and C. F. Curtis. 2004. Investigation of negative cross-resistance as a resistance-management tool for insecticide-treated nets. J. Med. Entomol. 41: 930-934.

Litchfield, J., Jr., and F. Wilcoxon. 1949. A simplified method of evaluating dose-effect experiments. J. Pharmacol. Exp. Ther. 96: 99-113.

Moncayo, A. 2003. Chagas disease: current epidemiological trends after the interruption of vectorial and transfusional transmission in the southern cone countries. Mem. Inst. Oswaldo Cruz 98: 577-591.

Monteiro, F. A., R. Perez, F. Panzera, J. P. Dujardin, C. Galvao, D. Rocha, F. Noireau, C. Schofield, and C. B. Beard. 1999. Mitochondrial DNA variation of Triatoma infestans populations and its implication on the specific status of T. melanosoma. Mem. Inst. Oswaldo Cruz 94: $229-238$.

Oppenoorth, F. J. 1984. Biochemistry of insecticide resistance. Pestic. Biochem. Physiol. 22: 187-193.

Panzera, F., J. P. Dujardin, P. Nicolini, M. N. Caraccio, V. Rose, T. Tellez, H. Bermúdez, M. D. Bargues, S. MasComa, J. E. O'Connor, and R. Pérez. 2004. Genomic changes of chagas disease vector, South America. Emerg. Inf. Dis. 10: $438-446$.

Picollo, M. I., E. Wood, E. N. Zerba, S. A. Licastro, and M. A. Rúveda. 1976. Laboratory test for measuring toxicity of insecticides in Triatoma infestans, Klug. Acta Bioquim. Latinoam. X: 67-70.

Picollo, M. I., C. V. Vassena, P. L. Santo Orihuela, S. Barrios, M. Zaidemberg, and E. Zerba. 2005. High resistance to pyrethroid insecticides associated with ineffective field treatments in Triatoma infestans (Hemiptera: Reduviidae) from northern Argentina. J. Med. Entomol. 42: 637642.

Porcasi, X., S. S. Catalá, H. Hrellac, M. C. Scavuzzo, and D. E. Gorla. 2006. Infestation of rural houses by Triatoma infestans (Hemiptera: Reduviidae) in southern area of Gran Chaco in Argentina. J. Med. Entomol. 43: 1060-1067.

Ramasubramanian, T., and A. Regupathy. 2004. Pattern of cross-resistance in pyrethroid-selected populations of Helicoverpa armigera Hübner (Lep., Noctuidae) from India. J. Appl. Entomol. 128: 583-587.

Robertson, J. L., and H. K. Preisler. 1992. Pesticide bioassays with arthropods. CRC, Boca Ratón, FL.

Rose, R. L., L. Barbhaiya, R. M. Roe, G. C. Rock, and E. Hodgson. 1995. Cytochrome P450-associated insecticide resistance and the development of biochemical diagnostic assays in Heliothis virescens. Pestic. Biochem. Physiol. 51: 178-191.

Santo Orihuela, P. L., M. I. Picollo, P. González Audino, S. Barrios, E. Zerba, and H. Masuh. 2006. 7-Coumaryl permethrate and its cis- and trans-isomers as new fluorescent substrates for examining pyrethroid-cleaving enzymes. Pest Manag. Sci. 62: 1039-1044.

Sauphanor, B., A. Cuany, J. C. Bouvier, V. Brosse, M. Amichot, and J. B. Berge. 1997. Mechanism of resistance to deltamethrin in Cydia pomonella (L.) (Lepidoptera: Tortricidae). Pestic. Biochem. Physiol. 58: 109-117.

Segura, E. 2002. El Control de la enfermedad de Chagas en la República Argentina, pp. 45-97. In A. C. Silveira [ed.], El Control de la enfermedad de Chagas en los países del Cono Sur de América. Pan American Health Organization, Washington, DC.

Sokal, R., and F. Rohlf. 1980. Introducción a la bioestadística. Editorial Reverté S. A., Barcelona, Spain.

Ullrich, V., and Weber, P. 1972. The O-dealkylation of 7-ethoxycoumarin by liver microsomes. A direct fluorometric test. Hoppe Seylers Z Physiol Chem. 353: 1171-1177.

Vassena, C. V., and M. I. Picollo. 2003. Monitoreo de resistencia a insecticidas en poblaciones de campo de Tria- 
toma infestans y Rhodnius prolixus, insectos vectores de la Enfermedad de Chagas. Revista de toxicología en línea 3. (http:// sertox.com.ar/ retel/n03-004.pdf).

Vassena, C. V., M. I. Picollo, and E. N. Zerba. 2000. Insecticide resistance in Brazilian Triatoma infestans and Venezuelan Rhodnius prolixus. Med. Vet. Entomol. 14: 51-55.

Vassena, C. V., C. Vassena, M. Ines Picollo, P. Santo Orihuela, and E. Zerba (2007). Desarrollo y manejo de la resistencia a insecticidas piretroides en Triatoma infestans: situación en Bolivia. In M. R. Cortez [ed.], Triatominos de Bolivia: Triatoma infestans, principal vector de la enfermedad de Chagas en Bolivia. Ministerio de Salud y Deportes, La Paz, Bolivia.
[WHO] World Health Organization 1994. Protocolo de evaluación de efecto insecticida sobre Triatominos. Acta Toxicol. Arg. 2:29-32.

Wilkinson, C. F. 1983. Role of mixed function oxidase in insecticide resistance, pp. 175-207. In P. Georghiou and T. Saito [eds.], Pest resistance to pesticide. Plenum., New York.

Yang, Y., Y. Wu, S. Chen, G. J. Devine, I. Denholm, P. Jewess and G. D. Moores. 2004. The involvement of microsomal oxidases in pyrethroid resistance in Helicoverpa armigera from Asia. Insect Biochem. Mol. Biol. 34: 763-773.

Received 25 April 2007; accepted 8 November 2007. 